\title{
Exploring the Irony in Japanese Popular Culture. \\ A Cross-Cultural and Linguistic Analysis.
}

\author{
Crînguța Irina Pelea
}

Titu Maiorescu University, Romania

\section{Изучване на иронията в японската популярна култура. Кроскултурен и езиков анализ}

\section{Крингута Ирина Пелеа}

Университет Титу Майореску, Румъния

\begin{abstract}
Author Note
Crînguța Irina Pelea

https://orcid.org/0000-0002-1080-9650

Crînguța Irina Pelea is Ph.D., lecturer in Titu Maiorescu University, Romania

The author has no conflict of interest to disclose.

Correspondence concerning this article should be addressed to Titu Maiorescu

University,22 Strada Dâmbovnicului Tineretului, București 040441. Email:

cringuta.irina.pelea@gmail.com
\end{abstract}

\section{Бележки за автора}

Крингута Ирина Пелеа (D) https://orcid.org/0000-0002-1080-9650

Крингута Ирина Пелеа е д-р, преподавател в университета Титу Майореску, Букурещ, Румъния.

Авторът няма конфликт на интереси.

Кореспонденцията относно тази статия трябва да бъде адресирана до Crînguța Irina Pelea, Университет Титу Майореску, 22 Strada Dâmbovnicului Tineretului, București 040441. Email: cringuta.irina.pelea@gmail.com 


\begin{abstract}
The present study addresses the status and use of irony in Japanese popular culture by closely examining its' cultural variations on a corpus consisting of ironic utterances and situations from three popular culture media: Japanese drama, anime, and manga. While it is likely that Western popular culture abounds in ironic aesthetics and standpoints, the concept of "irony" faces cultural reconstruction within Japanese culture and society, a fact easily reflected in national media and cinematographic productions. In such cases, the cultural and linguistic distance between Japanese and English, and the striking difference, which exists between these two geographical and cultural contexts, increase the challenge interposed by the understanding and interpreting of irony. Moreover, on a conversational level, ironizing one's communication partner is considered socially unacceptable and penalised accordingly. It stands against the much-expected politeness and traditional Japanese concepts such as "honne" and "tatemae," which, if preserved, can create harmony in communication. In conclusion, the ambiguous definition of irony, together with the negative perception and reluctance of Japanese people towards its usage, has contributed to frequently branding irony strictly as a Western phenomenon. However, as the present research attempts to demonstrate, the usage of irony in Japanese popular culture embraces multifarious approaches, and it extends to reach the borders of semantics.
\end{abstract}

Keywords: Japanese popular culture, irony, TV drama, cross-cultural linguistic analysis

Резюме

Настоящото изследване разглежда статута и използването на иронията в японската популярна култура, като отблизо изследва нейните културни вариации върху корпус, състоящ се от иронични изказвания и ситуации от три медии за популярна култура: японска драма, аниме и манга. Въпреки че е вероятно западната популярна култура да изобилства от иронична естетика и гледни точки, концепцията за „ирония“ е изправена пред културна реконструкция в японската култура и общество, факт, който лесно се отразява в националните медии и кинематографичните продукции. В такива случаи културното и езиково разстояние между японски и английски и поразителната разлика, която съществува между тези два географски и културни контекста, увеличават предизвикателството, наложено от разбирането и тълкуването на иронията. Освен това, на ниво разговор, иронизирането на комуникационния партньор се счита за социално 
неприемливо и съответно се наказва. Той се противопоставя на много очакваната учтивост и традиционни японски концепции като „honne“ и „tatemae“, които, ако бъдат запазени, могат да създадат хармония в общуването. В заключение, нееднозначната дефиниция на иронията, заедно с негативното възприятие и нежеланието на японците да я използват, допринесоха за честото брандиране на иронията строго като западно явление. Въпреки това, както настоящото изследване се опитва да демонстрира, използването на иронията в японската популярна култура обхваща различни подходи, простирайки се до границите на семантиката.

Ключови думи: японска популярна култура, ирония, телевизионна драма, междукултурен лингвистичен анализ

ARTICLE INFO:

Original Article

Received: 24, 04.2021

Revised: 30, 05.2021

Accepted: 25, 10.2021 


\section{Exploring the Irony in Japanese Popular Culture. A Cross-Cultural and Linguistic Analysis}

According to the well-rooted classical approach very frequently quoted in the academia, there is a salient tendency of confining irony as a device to the Western literary discourse, asserting that irony and even sarcasm as employed by English speakers present consistent understanding difficulties or even inability of recognising ironic utterances for an overwhelming per cent of the Japanese native speakers.

Nevertheless, the main rationale behind this research is to countervail and challenge such beliefs and to invite to legitimate academic debate, by offering a better cultural and social understanding of the current state of irony in Japanese popular culture.

The decision of focusing on this particularly narrow field is motivated, first, by noticing the thin literature regarding this area, and second, by the necessity of comprehending "irony" as a cross-cultural device employed within Japan and the Japanese language through the realms of autochthonous popular culture.

The research distances itself, therefore, from the pragmatic, linguistic and semantic approach of irony in Japanese literature, and proceeds towards exploring "irony" exclusively in the context of Japanese popular culture, while favouring to some extent Japanese language academic resources, which have remained untranslated until nowadays, over the international scholastic discourse, characterised by the undisputable prevalence of English language resources.

Besides tacitly agreeing that the distinction existing between irony, sarcasm or satire remains blurred to Western societies and cultures as well, most authors are unanimous that irony is notably far more prevalent there compared to the Japanese contemporary cultural and social context. Furthermore, translocating the specific characteristics of irony in Japanese from the English language or in the reverse direction meets not only consistent technical obstacles but frequently leads to drastically altering the performance of the approach.

Thus, the ubiquitous pervasiveness of irony itself stands only to emphasise the linguistic and cultural distance between Japan and the English-speaking world, noticing that the existing differences in the perception and usage of this device could not imply whatsoever its limitation to the Western context. To propose that we can reasonably acknowledge the existence of irony 
within Japanese language and cultural geography of Japan, albeit not being easy to read for an untrained Western interpreter, becomes a seductive, yet thorny premise simultaneously.

Within the fluid and versatile context of globalisation, where Japanese popular culture has already reached an overwhelming level of popularity, the linguistic barrier remains, primarily, an intrinsically and culturally enhanced factor, which bears significant influence, both in the production and the reception process.

What makes irony so challenging to grasp within Japanese cultural and social context? Are there any specific strategies of (re)constructing irony in these media? In what manner are Japanese popular culture media capable of dictating a more widespread use of irony? How should we interpret irony as a rhetoric and stylistic device when associated with these media? Is there any relation between Japanese language dialects and the employment of irony, and if there is one, does it call for any particular strategies?

Although the present research attempts to answer to some extent the questions mentioned above, it would be overambitious to pretend it covers all the manifold varieties of irony within Japanese (popular) culture, nor venture to answer every possible theoretical issue raised by this overtly generous topic.

\section{The irony in Japan: a linguistic and sociocultural approach}

The irony, as a virtually omnipresent and pervasive linguistic device, imposes many various interrelated difficulties, from its definition. As Muecke (2020) has mentioned: "getting to grips with irony seems to have something in common with gathering the mist; there is plenty to take hold of if only one could. To attempt a taxonomy and definition of a phenomenon so nebulous that it disappears as one approaches is an even more desperate adventure. Yet, if, upon examination, irony becomes less nebulous, as it does, it remains exclusively Protean, Its forms and functions are so diverse as to seem scarcely amenable to a single definition." According to the same author, one of the most common and perhaps simplistic definitions of irony regarded more as a rhetorical figure of speech is being centred around ideas of „saying contrary of what one means," "saying one thing but meaning another," and "mocking and scoffing" (p. 3-4).

Furthermore, over the past few decades, much scholarships addressing irony concerning various academic field has pointed out that part of its complexity lies in the challenge of distinguishing it apart from satire, sarcasm, wit and black humour, going further to the process of successfully translating ironic utterances in strikingly different cultural contexts. 
However, the most common Japanese equivalents of irony, as referred to by most Japanese researchers, are「アイロニー・イロニー」(“airon’”, irony),「皮肉」(“hiniku”, sarcasm),「風刺」(“fuushi”, satire), and very often mentioned as similar and related,「嫌 味」 (“iyami”, snide, disagreeable and sarcastic comment, which is always considered to be rude, therefore socially and culturally unacceptable).

「アイロニー・イロニー」("aironî”, irony) represents the literal translation of the English word “irony”, and according to大辞泉 (Daijisen, Japanese language dictionary, Japanese version), the first two mentioned entries are (1)皮肉。あてこすり, literally meaning “sarcasm”, respectively “snide remark, indirect criticism”, and 2) 語。逆説, which can be translated as "rhetorical question" and "paradox".

“Irony" as the English word is, thus, overwhelmingly translated as 「皮肉」 (hiniku, sarcasm, 「皮」 (“skin”) + 「肉」 (“meat”), suggesting "raw humour”, a word which remains the most frequently used in the Japanese language when it comes to such rhetorical devices. The following concept often perceived as having an identical significance with "irony" is「反語」(“hango”, rhetorical question) (Sanseido Dictionary, 2011).

The Japanese definition and translation of "irony" seems to be, thus, problematic, given that Google frequently generates terms such as “sarcasm”「皮肉」, “rhetorical question”「反 語」 or even「嫌味」, “rude comment," in place of the expected result of “irony,”「アイロ ニー」.

Another interesting aspect worth mentioning is that not few are the Japanese academic sources who leisurely use 「アイロニー」(“airon̄”, irony) and 「皮肉」 (“hiniku”, literal translation: "sarcasm") apparently as identical synonyms without pointing out any relevant differences between these concepts (Utsumi et al., 2021).

Furthermore, the sociolinguist Seisaku Kawakami (1998) in his Japanese language study 「アイロニーの言語学」 - “The linguistics of irony” asserts, “Irony 「アイロニー」bears almost no meaning (in the Japanese language)" (p. 4-6). According to the same researcher, "irony and sarcasm can be considered as having almost the same meaning but strictly speaking, for us Japanese, the nuances of “sarcasm” and “snide, impolite comment” (「嫌味」, “iyami”) are powerful”. 
Besides the above-mentioned linguistic ambiguity, various semantic differences and impossibility of matching the definition of irony to how it perceived within the Western space, what adds cultural distinctiveness to this discrepancy is the unicity of Japanese culture, which through its values, standards, norms, and principles can be contradictory towards the usage of irony.

From this brief review of the literature we can extract several cultural vibrant concepts are worthy of mention as being firmly ingrained in the Japanese mentality, and through their constant interweaving in the nowadays-Japanese society, contribute to limit from the perspective of the common usage to a significant degree the employment of irony.

The first concept to be mentioned 「和」 ("wa", harmony), which holds a "preeminent position in the hierarchy of Japanese values" (Clark, \& Rohlen, 1976) emphasises the importance of maintaining the harmony within the group (p.47). For Japan as a collectivistic and highly traditional society, the premise for ensuring a prosperous future is maintaining at all costs the group harmony; thus, the individual cannot risk altering $\Gamma$ 和」, therefore deviating from the group norms and disturbing the consensus with ironic or sarcastic statements, which could hurt the others. The necessity of respecting the other blends in with the cultural attitude of building one's refusal towards a request ambiguously and indirectly, for the reason that it is considered rude and socially unacceptable to refuse someone bluntly.

As a hierarchical society, which also cherishes social order and authority during the communicational acts with one's elders or superiors, not only irony but also dissenting opinions are excluded, to avoid offending the conversation partner and to maintain the already mentioned group harmony. Besides, known as 「上下関係」 (“jougekankei”, hierarchical relationship) or in some academic and working environments. 「先輩·後輩」 (“senpai-kōhai relationship") This concept shares a deep connection with「和」 (“wa”, harmony) and adds another contextual restraint in the usage and frequency of irony (p.64-66),

Consequently,「恥」("haji”, shame) - or the related term sharing the same kanji, 「恥 ずかしい」 (“hazukashii”, embarrassing) - highlights how deeply ingrained in Japanese mentality are the cultural patterns of shame and guilt (Terazawa, 1985) also strongly related is the following concept:「優しい」, (“yasashii”, kind). Perceived as one of the most cherished 
positive qualities of a person, one cannot be "kind" and in the same time, "ironic", given that 「嫌味」 bears the connotation of "snide, sarcastic comment" towards someone (p.,114-16).

Finally, in Japan, the development of irony is dictated not only by harmony, the necessity of maintaining a high level of formality, the power of context and other fundamental social conventions but also by the perspective of inside, respectively outside (Adams et al. 2009). Otherwise said, the antinomic concepts of「内」 (“uchi”, private) versus「外」 (“soto", public), and「建前」(“tatemae”, overt, formal) versus「本音」(“honne”, covert, hidden) have the effect of adding even more formality to group relations and eliminating almost every possibility of engaging into spontaneous ironic utterances in the background of a natural setting.

It is worth acknowledging that even if these cultural concepts function as interrelated factors of contextual restraint, the irony is not absent, as one might think. Japanese linguists have endeavoured to capture specific features of irony in the Japanese language. Albeit this study direction does not represent the main objective of the present research, it becomes imperative also to mention several linguistic strategies used in conveying irony in the Japanese language.

As Furukawa Yuriko (2010) has pointed out, praising the conversation partner ( 「褒 め」, "home", praise) can be interpreted as a compliment, but considering the contextual dependence and the level of politeness, the praising can function as an ironic utterance (p.49$51)$.

Furthermore, intentional misuse of 「敬語」(“keigo”, Japanese language honorifics) can be considered the speaker's attempt of making an ironic assertion, especially if the speaker holds a much higher status than the addressee (Okamoto, 2002, p. 122-24).

Therefore, honorific speech levels such as 「尊敬語」or 「謙譲語」 may express, through the intentional incompatibility with the context and the social positions of the conversational partners, forms of sarcasm, irony or hyperbole and by defying the stereotypical patterns of use, they become markers of linguistic intimacy or even aggression. (Sakurai, 1994, p.4-6)

\section{Methods and materials}


Among the global responses towards Japanese popular culture media, it has been noticed a significant trend towards consuming anime (animation for TV programs and films), manga (comics for both magazines and books) and J-drama (Japanese drama series) preferentially.

As the main research method, we have adopted the qualitative content analysis, by studying various humorous ironic utterances and their English subtitles from three different Japanese popular culture media genres: J-dramas, manga and anime.

Furthermore, in this paper we have limited ourselves to making reference strictly to the humorous functions of irony to outline a sample of ironic utterances.

The following sections will also include specific examples of ironic utterances, extracted from these three specific media of Japanese popular culture and analysed accordingly.

Before we proceed, though, a few brief observations are in order about the focus, aims, and concerns of the following subsections. While the first subsection focuses more on the various and expressive capacities of creating irony in J-drama and on exemplifying through one selected production how various dimensions of this medium can convey mostly dramatic irony, the last one devotes its attention towards the matter of interpreting irony in anime and manga, by focusing on a single production.

\section{Results and Discussion of irony in Japanese popular culture}

As a sample standing for the genre of Japanese dramas, we will shift our attention towards "Hero" (2001), one of the Japanese TV drama with the highest ratings of all times, which has played a pivotal role in the dissemination of Japanese language content in East Asia after the year 2000 .

\section{Enfolding irony in J-drama}

With record ratings for over 25 years, it was followed by the 2006 miniseries, the second 11-episodes series (2014), and the feature film entitled "Hero: The movie" (2007). The narrative line mainly follows the life events and career as a prosecutor of Kohei Kuryu, a former juvenile delinquent and his unorthodox way of solving legal cases.

The subsection will consist almost entirely of close analyses of scenes and moments where décor, performance, the evolution of the narrative line, and mise-en-scène intertwine to create irony in disparate episodes. It may be worth beginning our analysis with a particular radical example of dramatic irony, in the first episode's scene, more precisely the moment his soon-tobe colleagues and Kuryu are acquainted. What contributes to enhancing the dramatic irony is 
the high degree of discrepant awareness between the expectations of prosecutors' team towards the new coming prosecutor from Aomori Prefecture versus the reality they will soon face.

In the creation of dramatic irony, of significant contribution can be the mise-en-scène, more specifically, the relation between the characters' dialogue in the scene of their first meeting, and their unawareness of talking about Kuryu in his very presence, which bears an equally indispensable aural contribution to enhancing the irony, all together with alternating moments of pregnant silent and music. Manifold aspects combine to create and enhance irony in this scene.

First, there is a flat contradiction between the way his colleagues expect him to be (arrogant, hard to work with, displaying a superiority complex and a bossy attitude) and what they and subsequently the audience see of the lead character, as a consequence of a variety of elements, from costuming, performance or décor. On a side note, the mere presence of the broken TV in the meeting room and the image of Kuryu focusing his attention towards fixing it, while his new colleagues eagerly criticise him brings a sustained sense of dramatic irony.

Second, regarding the connection between the mise - en - scène and the characters' dialogue before and after becoming aware of Kuryu's identity as their new colleague and not as the unworthy-of-their-attention employee fixing their TV: from that point on, each line of the dialogue creates the dramatic irony.

Thirdly, the framing of the camera when all the characters are in the same room and soon to be acquainted is such that, by the end of this three-minute scene, the audience is nevertheless left in little doubt about the pronounced instance of dramatic irony one is witnessing. Here, the camera plays a significant contribution of stressing the stark contrast in degree of knowledge between the audience and characters; hence, it favours the viewer, by granting him a superior perspective in observing the characters' body language, respectively their emotional and verbal response when confronted with the reality.

Finally, we should note the reasonable sense of exaggeration, which marks the climax of their first moment as a team, more specifically the moment they all become aware of Kuryu's identity as their new colleague and not as an obscure technician repairing the TV.

Moving forward, the portrait itself of Kohei Kuryu as a prosecutor within the national and sociocultural context of Japan is ironic, given the striking difference between the social expectations and the behaviour he exhibits. He acts contrary to the image of a Japanese 
prosecutor, and he seems to care nothing at all, about what others think about his unorthodox workstyle, the reason why disregarding any external opinion can easily imply he is immune to any amount of ridicule.

The very excessiveness of portraying Kuryu as the perpetual nonconformist - addicted to TV shopping channels, an avid consumer of anime, with his creative, yet bizarre clothing style bearing a notable difference compared with his colleagues' formal dressing code abounding in dark colours - encourages the viewer to almost consider it a parody of the prosecutor's traditional and conservative image in Japan. The comical, sarcastic depiction of Kuryu performs, thus, a relief from the pressuring social conventions outside the drama, by outbalancing other characters' seriosity, pomposity and pretensions of superiority.

Moreover, within the first ten minutes of the first episode, the viewer is acquainted with all the characters, which in fact, represent nothing more than excessive visual embodiments of various clichés, albeit culturally coded. The subsequent scenes reveal, for instance, paralegal Maiko Amamiya as the hard-working girl hiding her prettiness behind an old fashion pair of glasses, and prosecutor Misuzu Nakamura as the unmarried career-driven woman, somewhat frustrated with her condition and getting older. Thus, depicting professional life as a prosecutor or a paralegal in Japan is deliberately exaggerated as to serve the ironic intentions.

The narrative line of the drama has a strong tendency of being national, to some extent even locally inflected, and thus it is excessively using specific regional idioms (Tokyo), anecdotes or activating some particular stereotypes or clichés. According to one of these narrative and visual clichés, every person from Aomori Prefecture must be eating many apples, given that this prefecture is famous for its' apple production; the hero, however, proves to be the exception and has the least of interest towards apples, compared to his co-workers. In such situations, the audience witnesses the creation of similar, yet striking contrasts between words or the expected behaviour from the protagonist and the reality against which they ironically clash.

(Kenji Endo) 青森ですからね 何か分かりやすく, リンゴか何か 持ってくるんすよ。 (ST)

He is from Aomori. It is easy to see he will probably bring some apples. (TT)

$$
\text { (一同の笑い声) }
$$

Laughing together, background music. 


\section{(リンゴを置く音)}

The sharp sound of placing the bag of apples on the TV.

\section{つまらない物ですが。}

(Kohei Kuryu) It is just a small gift...

$$
\text { (00:11:31,129 --> 00:11:47,826, first episode) }
$$

However, probably one of the most instantly conspicuous aspects of how this scene addresses the viewers is the high degree of congruence created between jokingly assuming to receive apples as a gift and actually receiving the fruits, together with the rhetoric sound of the bag of apples when placed on the TV. The close alignment between this sound, the following silence and the characters' visual expressions has the ostensible purpose of reinforcing the comic effect. As a punctual conclusion regarding the observations stated above, this is just one of the many scenes of the drama, where the camera grants the cinematic audience visual superiority, given that we are allowed to observe simultaneously the actions and reactions of every character, while they cannot see themselves, nor acknowledge the irony of their performance.

Furthermore, not only through the plot which frequently turns fairly absurd but also through the ironically exaggerated depictions of particular characters, the viewer's encountering with such striking visual hyperboles frequently becomes a signal of alert over the possibility that certain cinematographic conventions are being treated with an ironic tone. For instance, it might be the case of a familiar occurring plot; let us consider, then, the marriage fraud scene in the third episode, which revolves around a cliché tear-jerking phrase:

\section{「生まれ変わっても一緒になろうね」(ST)}

"Even if we were born once again, we would still be together." (TT)

(00:02:57, third episode).

In the intrinsic sonic embodiment of all one is least likely to associate with the concept of "love", the image of a con woman saying these romantic words to allure her men victims into a fake marriage, plays a pivotal contribution to the ironic contrast, which it is displayed both on a semantic and visual level. Simultaneously, the background music infusing this scene makes a decisive contribution in creating and emphasising the irony tied to contrast arisen between the literal and contextually implied meanings of "love". 
Understanding the drama's narrative lines at the most basic level, thus being capable of "reading" the irony involves grasping the characters' motivation of speaking ironically at a particular moment and in a certain way. Being one of the most frequently used strategies for shaping dramatic and conversational irony in many J-dramas, employing "fake politeness" has manifested manifold expressive possibilities of performance but bears cultural connotations, which might be missing, for English-speaking audience. The chosen drama for this study makes no exception from this tendency, be that there is an intentional misuse of 「尊敬語」 or 「謙 譲語」, to mixing in the same sentence both colloquial and polite expressions of a high degree. Reflecting this strategy is a particular scene of the first episode when, asked by her superior if she agrees with his decision, Ms. Nakamura replies nonchalantly:

(Misuzu Nakamura) わたしの決めることじやありませんからご自由に。(ST)

It is not something for me to decide, so please do as you wish. (TT)

$$
\text { (00:04:40,802 --> 00:04:42,804, first episode) }
$$

We should note the colloquial form of “じゃ” versus the polite version of 「ご自由 に」, both emerging into revealing fake politeness with ironic purpose, albeit with the cost of losing this linguistic nuance during the translation process.

Another relevant example reflecting how fake politeness conveys into situational irony is as it follows. After listening to his new colleagues' brutal, harsh and unjustified opinion about him, Kuryo presents the bag of apples as a gift by saying the usual「つまらないものです が」, meaning, in fact, everything but modesty (in translation, "My humble gift does not mean much...", an expression frequently used when handing gifts and omiyage, first episode, min 11:45.). We should interpret the irony of this scene while attending not only to words or their translation but also to the peculiar manner of their delivery, more specifically the tone and the rhythm of the protagonist' s voice. Besides the above-mentioned linguistic strategy, another one frequently used in this drama, to construct ironic situations is the intentional misuse of the compliment.

Nevertheless, the deceivingly playful and optimist nature of many scenes and lines, veil, in fact, an indirect criticism tacitly towards problematic issues of nowadays Japan's society: the excessive bureaucracy, the poignant presence of the "work-hard culture" or the low birth rate 
(albeit past their mid-thirties, almost none of the team's members has children and favours career over family life).

\section{Interpreting irony in manga and anime}

While there is an array of literature available on manga and anime as visual vehicles and leading brands of Japanese popular culture, the number of studies, which focus on investigating through what means the dramatic, situational or communicative irony is created and can be interpreted in these media remain scarce.

In addition, albeit manga and anime are not identical media, as transcultural commodities sharing a symbiotic relationship, they frequently tend to share a similar narrative line and a complementary visual style, reason why we opted for including them into the same subsection; hence, the following analysis applies for both the selected manga and anime productions serving as a sample.

To explore further the inquiry of how irony is elicited through this medium, let us consider, then, some of the most ostentatiously ironic and symbolic scenes, both in the manga and the whole 64 episodes anime series "Fullmetal Alchemist: Brotherhood", known under the original title of 「鋼の錬金術師」(2009-2010). Acknowledged as the second anime adaptation of the original "Fullmetal Alchemist" manga, authored by Hiromu Arakawa, it narrates the dramatic saga of the Elric Brothers, Edward and Alphonse. The adventurous journey of these two alchemists has the purpose of getting hold of the Philosopher's Stone, which, by surpassing the restrictive laws of alchemy, would allow Alphonse to recover the body he has once lost while trying to resurrect their mother by performing a prohibited alchemy technique. However, to transplant the bodiless soul of Alphonse into a suit of armour for saving his life, Edward paid the price of giving up his arm.

Albeit many alchemic and philosophical ideas infuse the narrative line, let us reflect strictly on how irony is constructed around the idea of the seven Homunculi and their death. As artificially created human beings, they become significant and virtually immortal antagonists, revived by the power of alchemy, while each one of them embodies one of the Seven Deadly Sins, a fact otherwise reflected in their names, according to the sin that they represent: Pride

(プライド・傲慢）, Lust (ラスト・色欲), Greed （グリード・強欲）; Gluttony（グラ トニー・暴食）, Wrath（ラース・憤怒）, Sloth（スロウス・怠惰）, and Envy（エンヴ ィー・軼妬）. At this point, we should acknowledge that both the manga and anime are 
unmistakably blending, juxtaposing and subverting themes or leitmotivs associated in particular with Dante's poem “Inferno", where we can find mention of the seven sins. Another source of appropriation of this familiar cultural and spiritual imagery can be identified as partially originating from the Buddhist concept of 「煩悩」, as in "the worldly desires", which include “Pride” (慢), “Greed” (貪), and “Wrath” (顚).

Powered by the energy of the magical Philosopher's Stone, each one of the Homunculi is granted with a unique set of abilities and superhuman strength, which makes them almost invincible. Their death, however, is highly ironic. In order to illustrate this statement, let us, then, proceed to examine the following seven examples of ironic deaths, while analysing and interpreting the intertwinement of irony with the symbolic death of each Homunculus.

Pride's death is, by far the more ambiguous of all, thus should not be interpreted in the literal meaning of the word, but rather as being defeated, which leads to the vanishing of his sense of pride. As the first Homunculus created by the Father as an embodiment of his pride, the deceiving innocence and seemingly kindness of this Homunculus hide a cruel and versatile nature. The one to defeat Pride is Edward Elric, one of the main protagonists, whose personality presents, ironically, little trace of humbleness in the first part of the series. Albeit Pride, as the most powerful of the Homunculi and by far Father's favourite, despises humanity and manifests a superiority complex towards the human condition, he finds himself forced by unfavourable circumstances to attempt taking as a host Edward's human body, whereas in the object of his long-time despise. However, the irony of Pride's faith lies clearly, not only in the manicheistic confrontation he has with a much-despised human but also in the ostentatiously intense contrast created in the final scene: the narcissist Pride, doomed to live among humans, without any special abilities nor memories of his evil past, starting his journey as an innocent babe. This moment becomes, thus, the metaphoric death of Pride, who will be reborn and learn the lesson of humility and modesty.

As the first Homunculus to die, Lust is depicted as a charming, lascivious, and manipulative villain and embodies, as her name suggests, the capital sin of carnal pleasures, reason why her imagery as the only female out of the seven Homunculi is highly objectified and physically sexualised through her breasts and lips. Through her deceptive and attractive nature, Lust makes slaves out of the weak ones, turned into mere captives of their worldly desires. Nevertheless, the one who exterminates Lust is Colonel Mustang, a man with the 
reputation of a Casanova, therefore consumed by lust himself, at least to some extent. There are two striking aspects, which contribute to the ironic intensity of this narrative moment. First, albeit the masculine portrait of Colonel Mustang is infused with passionate anger while carrying within many blind ambitions and an irrational lust for power and revenge, none other but himself manages to reduce Lust to ashes. Moreover, what adds a striking ironic effect to the symbolism of this particular death scene is that he also succeeds into bringing Lust on her kneeling position, just like every other victim who has submitted to her lewdness.

Greed's character, the last Homunculus to perish, proves to be contradictory, to the point that he surprised the audience by revealing a genuine and unexpected innocence when he opted to sacrifice himself for the noble and romantic ideal of having friends. The higher the so-called claims of greed, by continually emphasising through the series his attachment towards worldly and wholly malicious desires such as fortune, power, and even immortality, the higher is the irony of his self-destruction. Moreover, albeit his persistent quest of achieving immortality, he has to die to achieve his not that greedy spiritual thirst of having friends. Greed's final and uncharacteristically compassionate act of self-sacrifice exposes how limited our perspective was and allows us to articulate essential impressions surrounding his image, by ironically evoking our compassion, and overall, encouraging our feelings towards a finale and positive evaluation of this Homunculus. Once again, the irony lies in the sharp contrast between the surface meaning of his previous words and behaviour versus the authentic greatness of his final desire.

Albeit included in the list of the seven deadly sins, Gluttony, by symbolising overindulgence and over-consumption of food, drink or wealth and status-related items, has probably a less influential negative impact, compared to the other sins. In the context of this anime series, it might be possible that Gluttony's representation, both on the visual and verbal level, constitutes, among other things, a parody of previous stylistic and technical conventions of anime and manga media, if we are to be taking into account the clichés, exaggerations and hyperbolic metaphors surrounding his image during the story. The prevailing innocent attitude displayed by Gluttony as an overly large and deformed man is often accompanied by the frequently repeated line "Can I eat him?", thus the attempted complementarity of his words and portrait makes perhaps the most decisive contribution to the irony pervading his scene of death. Gluttony dies eaten by the Homunculus Pride hungered for power. 
By symbolising the intense, vengeful human anger, Wrath's character is represented as the only Homunculus capable of ageing, an older man whose left eye grants him the power of seeing beyond the limits of the physical world, thus bringing him to the edge of invincibility. The one who succeeds in defeating Wrath is none other but a serial killer by the name of Scar, whose desire for revenge and inner anger leads him to hunt and exterminate every State Alchemists there is. Witnessing the destruction of his own country by the State Alchemists transform Scar's wrath into the arm of destruction for the Homunculus with the same name.

The symbolism of Sloth goes beyond reflecting the mere laziness, but also the apathy and lack of care of one's inner self, objectified through the chains he wears, marking the enslavement by the sin of sloth. The main factor, which contributes to the destruction of this Homunculus is his torment of indolence, more specifically the unwillingness of continuing the fight when in the final scene, he abandons the confrontation with the Armstrong Brothers.

We might note several key contrasts regarding the imagery of Sloth: on the one hand, the incongruity arisen from his frequently asserted opinion about himself as "the fastest of the Homunculi", and on the other hand, the utter consonance between his signature line "What a pain!" reflecting his intimate way of thinking and his actions.

The final example of how irony can imbue the death scene of a Homunculus is the one of Envy who shares the same disdain towards human beings as Pride. These feelings turn to be the actual reason, which leads him to commit suicide when he acknowledges, ironically, that the object of his envy was the same with the one he long despised: humans. Opting for suicide represents, thus, a cathartic action, which can rectify, with one stroke, the ultimate humiliation he has felt upon this shameful discovery.

On a side note, although many English (and not only) speaking viewers would agree upon the ironic content of the aforementioned iconic scenes, a highly contrastive approach of reception catch our attention, at the attempt of searching on Google, in the Japanese language, the following keywords: 「鋼の錬金術師・ホムンクルス・人造人間・死亡」，in translation "Fullmetal Alchemist", "Homunculus", and "death". Out of the first 284 Google results referring to the same situations as interpreted above, none has returned the words “irony", "ironic” or even "sarcasm", as in「アイロニー」 or「皮肉」. Instead, some frequently mentioned descriptive words for the scenes we have referred to are 「教訓」as in “lesson”, “precept”, “teaching”, 「因果」, as in "karma” or “fate”, and 「象徵」, meaning 
"symbol". This observation of seemingly minor importance should make us reflect if the underlying semiotic and sociocultural significance of "irony" as rhetoric and literary device shifts during the translation process from English into Japanese or in the reverse direction.

Thereby, we can extend the research horizon by addressing a potential question to explore further, of whether "irony" signifies particular and, to some extent, different meanings according to the context - Western or Japan - in which it occurs.

\section{Conclusions}

The present research aimed to contribute not only to the cross-cultural studies of irony in Western versus Japanese context but also to offer a better understanding of irony employed strictly as a device in Japanese popular culture, given that very little work has been dedicated to investigating this particular topic. Through the above selected Japanese media and products, we have thus explored to some extent each medium's capacity for ironic expression and investigated how some of its properties and particular devices can be used to create and, subsequently, enhance the ironic effect. Nevertheless, of course, in order even to consider any of the samples as being ironic or including ironic utterances and moments, one first has to interpret them as ironic.

Each of the above media has demonstrated, through the selected productions serving as samples for analysis, expressive possibilities of creating various types of irony, albeit by displaying disparate approaches to irony, a reasonable fact, given their different defining characteristics. Therefore, we can disagree with the strong assumption still existing on the part of both Western researchers and audiences that irony is exclusively limited to the Western context. Nonetheless, while we cannot whatsoever constrict a medium to generating one particular type of irony alone, anime and manga appeared particularly capable of depicting situational irony. At the same time, the J-drama offered, from our perspective, a significantly more convincing account of dramatic irony.

Another essential conclusion we can draw is that irony, in Japanese popular culture, is reinforced by the existence of a deep-rooted cultural and linguistic dimension - always in excess, we might add. However, as a general observation, regardless of the high importance of this linguistically and culturally faceted dimension, we should avoid the fallacy of identifying irony too closely with a specific nationality. 
Furthermore, if irony will reach its destination depends mainly on the public, otherwise in the role of the interpreter, capable or not of establishing an intimate connection, both on a semantic and cultural level with the Japanese (language) content. Otherwise said, whether or not one will even regard any moments as ironic at all, then, assuredly depends on one's interpretative judgement and capacity to connect on a deeper level to those as mentioned above Japanese cultural background.

Finally, to conclude on the comprehension of irony within this cultural context, we can assert that understanding and reading irony as employed within Japanese popular culture frequently requires for the interpreter's ability of grappling cultural, usually unspoken, and highly sensitive issues. Against this background, it makes sense to read irony in Japanese popular culture through both the conceptual lenses of culture and language simultaneously. This situation usually becomes possible only if one possesses a high(er) familiarity with the Japanese language, at least an above-average degree of direct or indirect shared cultural experience with Japan, and awareness of recognising visual conventions and specific imagery of various Japanese popular culture media such as anime, manga, and J-drama.

\section{References}

Adams, A., Murata, K., \& Orito, Y. (2009). The Japanese sense of information privacy. AI \& SOCIETY, 24(4), 327-341. doi: 10.1007/s00146-009-0228-z

Arakawa, H. (2021). Fullmetal alchemist: brotherhood. [Original Title 鋼の錬金術師].

Square Enix's Monthly Shōnen Gangan.

Clark, R., \& Rohlen, T. (1976). For harmony and strength: Japanese white-collar organization in anthropological perspective. Man, 11(4). https://doi.org/10.2307/2800477

Irie, Y. (2009). Fullmetal alchemist: brotherhood. Original Title 「鋼の錬金術師」[Film]. Tokyou; Bones Inc., 株式会社 ボンズ.

Fanblogs. ファンブログ / 高機能なブログを無料作成. (2021). Retrieved June 10, 2021, from http://fanblogs.jp/matomest/archive/9/0.

Furikawa, Y. (2010). When a compliment sounds sarcastic or offence. [Original title Гほ め」が皮肉や嫌みになる場合. 日本語・日本文化]. Osaka University Knowledge Archive, 36, 45-57. Retrieved 2021 April ,17. 
Kawakami, S. (1998). Toward a unified theory of linguistic irony. [Original title アイロニー の言語学. 紀要論文]. Departmental Bulletin Paper of Graduate School of Letters, 32, 1-17. Osaka University, Retrieved May 11, 2021, from https://ir.library.osakau.ac.jp/repo/ouka/all/47941/mrl_032_001A.pdf

Muecke, D. (2020). The compass of irony. Milton: Taylor \& Francis Group.

Okamoto, S. (2002). Politeness and the perception of irony:honorifics in japanese. Metaphor And Symbol, 17(2), 119-139. doi: 10.1207/s15327868ms1702_3

Sakurai, Y. (1994). Politics of 'irony' in communication: a hypothetical answer by 'senseanxiety'. [Original title コミュニケーションにおける「皮肉」のポリティックス : 「意味不安」による仮説的回答案]. Departmental Bulletin Paper, Kagoshima University, 2. Retrieved 2021, April 10 from http://hdl.handle.net/10232/14978 Shogakukan. (1995). Daijisen 大辞泉 Daijisen [Japanese Dictionary; Japanese Edition]. Sanseido Web Dictionary. (2020). [ 三省堂辞典]. Retrieved April 10, 2021, from https://www.sanseido.biz/. https://www.sanseido-publ.co.jp/sp/wbdct_close.html Suzuki, M., \& Sawada, K. (2001). Hero. [ Original Title 「ヒーロー]」. [Film]. Fuji TV. Terawasa M. (1985). Shame and shyness. [Original title 羞恥>の構造(上):「恥の文化」三 考]. Hitotsubashi journal of social sciences, 10(3), 109-126. Retrieved 2021,March, 17 from https://hermes-ir.lib.hit-u.ac.jp/hermes/ir/re/6150/kenkyu0100301090.pdf Utsumi, A. (2021). Recent development in irony studies. 31, 49-50. [Original title アイロニ 一研究の新 展開. 日本認知科学会]. Retrieved 2021, May 5 from https://www.jcss.gr.jp/meetings/JCSS2014/proceedings/pdf/JCSS2014_WS7.pdf. 